Journal of Teacher Education for Sustainability, vol. 16, no. 1, pp. 5-31, 2014

\title{
Mathematical Identity for a Sustainable Future: An Interpretative Phenomenological Analysis
}

\author{
Anita Pipere and Ilona Mičule \\ Daugavpils University, Latvia
}

\begin{abstract}
Individual in-depth, semi-structured interviews with three mathematics teachers were conducted to investigate the dynamics of their life-long relationships with mathematics, synthesised as mathematical identity from different identity positions in the context of dialogical self. The qualitative data were scrutinised employing interpretive phenomenological analysis that displayed mostly positive instrumental relationships with mathematics and explicit connections between the teachers' life experiences and their disctinct identity voices that surfaced in interviews. Similarly, teachers appeared to be experts in different professional spheres: pedagogy, subject or didactics. The teachers' accounts contain various models of relationships between the other-motive and the self-motive as reflected in their pedagogical approaches. Emergent patterns resulting from the interaction of the teachers' mathematical identity and their perception of students' mathematical philia/phobia included the humanistic approach with an instrumental interpretation of mathematics and its teaching methods, self-actualisation in achieving success in mathematics through hard work and the issue of attribution of failure in mathematics either to external or internal factors. Moreover, these dialogical models and interactive patterns show alignement with one of the core competences for educators in education for sustainable development, that is, achieving transformation in what it means to be an educator, in teaching and learning, as well as in the entire education system. Practical implementation of findings and limitations of the study are outlined along with venues for future research.
\end{abstract}

Keywords: mathematical identity, mathematics teachers, dialogical self, competences for educators in education for sustainable development, interpretative phenomenological analysis, social constructionism

\section{Introduction}

In order to reach sustainability in education in a broad sense, we have to seek untraditional and creative solutions, such as interdisciplinary approaches and innovative ways of dealing with routine problems. One of the possibilities in this regard is to look at educational discourse through the lens of an individual's identity as it gradually shapes synergetic relationships with the surrounding world in general and with specific areas of knowledge in a particular sense. 
The recent message of bringing sustainable future through education (Fien, 2003; Katzschner, 2011; United Nations Economic Commission for Europe [UNECE], 2011), changing educational system in general, transforming pedagogy, didactics or specifics of any subject, frames the global and local context of presented study. So far, mostly the specifics of subject content and teaching methods have been empirically studied in relation to different aspects of education for sustainable development (ESD) (Gerretson, Howes, Campbell, \& Thompson, 2008; Illeris, 2012; Jonāne, 2008; Renert, 2011; Sánchez, 2011). However, according to Reunamo's four-fold model for ESD research (Reunamo \& Pipere, 2011), the focus on the subject's content aligns solely with an assimilative orientation of the model, using mostly theoretical and quantitative points of view while an accomodative stance on understanding the motifs and discourse of sustainable development as a meta-content or meta-message (Salīte, Gedžūne, \& Gedžūne, 2009; Sund \& Wickman, 2011) could be found in qualitative research of individual participants' interactive processes (Reunamo \& Pipere, 2011).

Unfortunately, there are different avenues through which education often fosters unsustainable living. One of the most challenging issues in this regard is the competences of educators at all levels of education on how to implement ESD (UNECE, 2011). The UNECE Steering committee on ESD recently proposed guidelines for all educators in order to set the framework for their professional development since educators can become the main agents for change if they feel able and supported in their endeavour. In short, the UNECE (2011) guidelines "Learning for the Future" contain the core competences in ESD for educators. 1) A holistic approach seeks interrelation between integrative thinking, inclusivity and dealing with complexities. Within this approach, an educator comprehends the inclusive nature of education, the complexity of our life and its issues, the interrelation and interdependence of all existing. 2) While learning from the past, engaging with the present and exploring alternative futures, educators need to envision a change that can be reached by critically assessing different processes and inspiring hope for their learners. 3) Teachers need to participate in achieving transformation in what it means to be a educator, in teaching and learning and in the entire education system. Teachers need to become critically reflective practitioners who challenge unsustainable practices at all systemic levels. Since these competences were mandated quite recently, our study would be among the first to use them in empirical exploration of school teachers' experience (see also Sims \& Falkenberg, 2013; Van Poeck, \& Vandenabeele, 2013).

The sustainable identity of teachers could serve as a powerful tool for sustainable learning of their students. The teachers' identity molds their students' learning achievements and, ultimately, their own identity, and a path of life. Though the connection between the teachers' identity and ESD is a rather new departure in a field currently undergoing major revisions (Katzschner, 2011), it is urgent to observe these connections in a context of a socially and individually challenging discipline such as mathematics. The rational application of wisdom coming from science and mathematics might help us in designing a sustainable future if these disciplines are able to provide means to deal with specific environmental (or even social) issues endangering the future of our planet. At the same time, a global trend of the new millenium shows a sharp decrease in the number of students accessing mathematics undergraduate courses or entering professions connected with mathematics and natural science (Di Martino \& Zan, 2010). Thus, we need to find a way to make these areas of learning more in line with the capacities and 
needs of society, meanwhile fostering the social, cultural and psychological changes in educational processes aligning with the principles of sustainability.

In this paper, among other things, we attempt to show if and how the teacher's individual life experiences translated in terms of mathematical identity and dialogical self, if and how related patterns of personal pedagogical theories, in the context of mathematics teaching and learning, align with the competences for educators in ESD as mandated by UNECE. Initially, we shall examine the notion of mathematical identity, then the dialogical self as an intersection of different identity voices will be analysed in detail. The studies regarding the students' mathematical philia and phobia, in addition to teachers' perception of it, will be discussed. The idea about the teachers as reflective practitioners challenging unsustainability through the prism of their life and work will bridge agap between the teachers' personal reflections and the focused change necessary for sustainable practice. Furthermore, a qualitative approach to the study will be substantiated right before presentation of the aim and research questions. The traditional review associated with the research method will be followed by the results and a discussion containing illustrative descriptions and analyses of the three teachers' cases. The paper will end with conclusions on the topic, concluding with limitations of the study, practical implications and suggestions for further research.

\section{Mathematical Identity}

Today, in a situation of increasing ontological insecurity, existential uncertainty (Kinnvall, 2004) and exponential growth of knowledge, it seems more and more obvious that learning is not so much about obtaining knowledge as about the developing healthy, productive, adaptable identity (Pipere, 2003). Following the recent trends in educational research observing the notion of identity as a powerful and promising analytic tool (Gee, 2001; Kaplan \& Flum, 2012; Sfard \& Prusak, 2005), studies in mathematics education show a growing interest in identity as a structure helping to understand learners' engagement with mathematics. Although the main focus of identity research in mathematics education has been the identity of students (Anderson, 2007; Browne, 2009; Darragh, 2013; Esmonde, 2009; Nyamekye, 2010), several studies have been aimed also at identifying the mathematical identity of pre-service and in-service teachers (Brown, Jones, \& Bibby, 2004; Kaasila, 2007; Kaasila, Hannula, Laine, \& Pehkonen, 2006; Stinson, 2009) as it may be comprised among the agents of successful teachers' performance and students' positive mathematical identity.

In this study, engaging the phenomenological foundation for the understanding of more rarely studied in-service teachers' relationships with mathematics, we shalldraw on the definition of mathematical identity, reaching beyond the mere practices of doing school mathematics (Browne, 2009). In general, we shall position mathematical identity as a construct that describes the relationship of a person with mathematics (BiknerAhsbahs, 2003). Taking a more detailed view and following Martin (2007), mathematical identity will be considered as the dispositions and beliefs regarding an individual's ability to participate and perform effectively in mathematical contexts as well as to use mathematics to change the conditions of her/his lifes.

To explain the emergence and development of mathematical identity, we shalluse the standpoint of social constructionism, ocasionally used in research in the field of teacher education and training (Bainbridge \& Macy, 2008; Dobozy, 2012; Hawley, 
Crowe, \& Brooks, 2012). From this viewpoint, an identity is formed in relationships with others, extending from the past and stretching into the future (Wenger, 1998). In this regard, relationships with mathematics for the majority of adults in the Western world usually start during early childhood and are closely connected with main authobiograhical turning points (for instance, preschool, elementary school, secondary school, university, workplace etc.). In the years of formal education, as well as in non-formal and informal ways, learners come to know themselves in relation to mathematics through relationships and experiences with their peers, teachers, family and community (Anderson, 2007).

In terms of mathematics teachers, we may hypothesise the further development of their mathematical identity after the secondary school, in the university context while studying to become mathematics teachers and mainly in relationship to university teachers, peers and community; then, during the novice years, in a school context of interacting with mentors, colleagues, students, parents, school administration etc. Later, as experienced professionals, mathematics teachers can become involved in professional development courses, research, textbook writing, projects, preparing students for mathematics competitions, communicating with professionals and developing their own mathematical identity in a wide diversity of contexts. However, as all these relationships and interactions are in a continuous state of change, the content of the socially constructed mathematical identity evolve.

Drawing on an existent knowledge to grasp the content of a mathematics teacher's mathematical identity, we use the recent findings from Anderson (2007), Di Martino and Zan (2010) and Kaasila (2007). In line with Wenger (1998) and Gee (2001), Anderson (2007) describes four faces of mathematical identity. In the context of this paper, we adapt these faces to the "body" of in-service teacher's mathematical identity. 1) Engagement refers to the direct experience of teacher's engagement with mathematics her/his self-recognised and socially acknowledged level of competence in mathematics. 2) Imagination relates to how mathematics fits into teacher's other activities in the present as well as the future, and it also relates to what a deeper meaning of mathematics in a broader context of life is. 3) Alignment means that a teacher aligns his/her energy within institutional boundaries and requirements. In the case of in-service teachers, this could mean that those who consider, for instance, the latest developments in didactical approaches direct their energy towards changes in their teaching. 4) And the nature face of identity considers the teacher's biological inheritance (for instance, gender and race), which is beyond the teacher's control.

Di Martino and Zan (2010) in their study of students' relationships with mathematics highlight the three themes: emotional disposition towards mathematics (positive or negative), vision of mathematics (relational or instrumental) and perceived competence in mathematics (high or low). In a similar vein, Kaasila (2007) discerns the pre-service mathematics teachers' views of 1) themselves as learners and teachers of mathematics, 2) mathematics and its teaching and learning and 3) the social context of learning and teaching mathematics.

Therefore, in integrating these suggestions, we can assume that the mathematics teacher's mathematical identity as based on biological inheritance would include: 1) relationships with mathematics in a broader context of life of its teaching and learning; 2) self-recognised and socially acknowledged competence as a mathematics' learner and teacher and 3 ) the social and institutional context of learning and teaching mathematics. 
Since social constructionism emphasises the use of language as a tool for social interaction and construction of identity in describing the procesual and expressive nature of mathematics identity, we should conceive of it as a constantly developing narrative designating both a person's self-understanding as well as how others see that person in the context of doing mathematics. Mathematical identity results from the negotiation of our own assertions and the external evaluations of others (Martin, 2007). It is a context bound as people justify, explain and make sense of themselves in relation to mathematics and to other people acting in mathematical communities, depending on the audience and social conventions of how language is used (Kaasila, 2007).

The temporal context of mathematical identity, moving from the past, through the present, and to the future, indicates the suitability of authobiographical reflections to deconstruct the relationships and institutional contexts in relation to the identity of the teacher. These reflections can serve, in a practical sense, as an interpretative framework for professional actions explained as "tacit knowledge," where a self-image and task perception have roots in early childhood relations, interactions with significant others throughout the teaching career and critical periods of life (Swennen, Volman, \& van Essen, 2008).

The teacher's autobiography bound to mathematical identity involves personally meaningful episodes, important persons and institutions, rationalisations and explanations, as well as the development of his/her beliefs aboutlearning and teaching mathematics. Our task as the researchers is to elaborate on how a person's earlier experiences influence his/her past and present mathematical identity (Kaasila, 2007).

As the mathematical identity certainly is not the singular identity of a mathematics teacher, the dialogical character of a teacher's identity voice is described further.

\section{Dialogical Self of the Teacher: Interaction of Identity Voices}

Dialogism is conceived as an explicit attempt to rise above the intersection between identity and learning. Education can develop identity through specific learning mechanisms, and this development can become an important goal for education. The approach of Dialogical Self Theory (DST) can be very useful for education as it focuses on the self as influenced by context and social interaction (Ligorio \& Cesar, 2012). According to DST, the self is a polyphony of voices or different I-positions constantly stiving for change and for a balance between various tensions among them (Hermans \& Dimaggio, 2004; Hermans \& Hermans-Konopka, 2010). The DST is also applicable when shifting a focus from the student to the teacher.

In their profession, teachers interact with different groups of people (for instance, students, parents, colleagues, administration and researchers) within different contexts (for instance, school, society, further education) and sub-identities (for instance, teaching, counselling, research) (Vloet \& Jacobs, 2013). At the same time, in terms of the content, a teacher's professional identity can be related to core teaching aspects such as didactical and pedagogical expertise as well as the subject matter. A teacher, as an expert inthe subject, has a profound knowledge base in his/her subject(s). As an expert in didactics, he/she knows how to teach specific subject-related content, emphasising creation of learning environments that support the pupil's learning process, and, as an expert in pedagogy, a teacher understands human thought, behaviour and communication to support the child's development as a human being (Beijaard, Verloop, \& Vermunt, 2000). 
The interactive, procesual and contentwise aspects of a teacher's professional identity mentioned above participate in a constant interplay with other sub-identities or possible teacher's voices, unremittingly searching for the meaning of these interactions. According to Hermans (1991), while constructing the meaning of the self, the individual grounds the self on two basic motives: the self-motive aims towards self-expression, self-development and self-defence while the other-motive strives towards the unity with others and belonging to a larger entity. The experiences of these motives can elicit positive, negative or ambivalent feelings (Hermans, 1991). Revealing the basic motives would help to understand mathematics teachers' personal philosophy of education and, specifically, their relationships with a concrete discipline.

In our study, the "self" of the mathematics teacher is reflected both within a phenomenological tradition as an experienced and enlived reality and constructed as a narrative in a specific context and at a given time (Hermans \& Hermans-Jansen, 1995). According to Vloet and Jacobs (2013), a professional identity can be seen as a constructed set of stories told by the teacher in relation to others. We resort to the single, yet interrelated, aspect of mathematics teachers' professional identity, that is, their mathematical identity as embedded in a specific scientific discipline and a subject taught at school.

\section{Teachers' Perception of Students' Mathematical Phobia and Philia}

In the context of this qualitative study, we ground the notion of mathematical phobia in a broader discourse, binding it not only to affect-oriented constructs like mathematical anxiety, as generally displayed through the physiological symptoms of negative emotions (e.g., fear) having to do mathematics (Hembree, 1990; Ashcraft, 2002) or of negative attitudes towards mathematics as conceiving its emotional, cognitive and conative aspects (Di Martino \& Zan, 2010; Domino, 2009; Hannula, 2002; Zan \& Di Martino, 2007; Zan, Brown, Evans, \& Hannula, 2006), yet embracing all complexity of factors that causes failure dealing with mathematics in different contexts. In a similar way, the notion of mathematics philia will be connected with a wide array of factors fostering the successful mastering of mathematics not only in the classroom, but in all life situations.

The literature does not bring us thorough empirical evidence of the causes of mathematical phobia, though some studies find it rooted in early school experiences (Humphrey \& Hourcade, 2009; Pan \& Tang, 2004) or connected with teaching based on high demands and little support (Turner et al., 2002). Some studies dealing with mathematical phobia (Humphrey \& Hourcade, 2009; Woolfolk, 2007) mainly advocate for a change in teaching and learning to reduce competition, clarify instructions, minimise time and other pressures, collaborate with a skilled partner, start with small achievements to generate initial success etc. Also, to invoke mathematical philia, passionate teachers with love towards the subject are needed (Rameau \& Louime, 2007). Very few studies focus on the mathematical teachers' perception of their students' mathematics phobia and philia (Insook, 2009; Wilbert, 2008; Zan \& Di Martino, 2007). In general, teachers attribute the causes of a negative attitude towards mathematics to students' characteristics and behaviours, for instance, lack of interest and effort by students, thus hiding the teacher's responsibility forcreation of such an attitude. While Zan and Di Martino (2007) reveal that teachers' diagnosis of students' "negative attitude" (p.162) towards mathematics presumably is a final result of teachers' interpretation of students' issues, 
in our study, we went further and directly asked teachers to explain their view on the causes of the students' mathematical phobia and philia.

\section{Teachers as Reflective Practitioners: Challenging Unsustainability}

As mentioned in the introduction of this paper, only by becoming critically reflective practitioners teachers will be able to challenge unsustainable practices at all levels of the educational system, ranging from identity development of the learner to the inclusive societal contexts of economic, cultural and political evolution.

The term "reflective practice" has multiple meanings that range from the idea of professionals engaging in solitary introspection to that of engaging in critical dialogue with others (Finlay, 2008). In this study, we are looking at teachers as reflective practitioners in a collaborative dialogue with the researcher. Moreover, according to Larrivee (2000), the examination of one's teaching from the position of a reflective practitioner enriches one's professional identity. The literature about reflective practice starts from Dewey (1933) and is followed by Schon's (1983) seminal work that emphasises the development of reflective practitioners and suggests two types of reflection: reflectionon-action and reflection-in-action. The presented study is linked with teachers' reflectionon-action, namely, thinking after the event, where teachers consciously review, describe, analyse and evaluate their past practice with a view to gaining insight to improve their future practice (Finlay, 2008). In some cases, in developing educational systems, the system itself is not conducive for such a kind of reflection-on-action, limited by, for instance, a lack of teachers' autonomy, the absence of a culture of openness and questioning, time, the lack of financial and other resource constraints, among other things (Sangani \& Stelma, 2012).

The plethora of literature points to the connection between the professional's reflection and change in his/her practice. As Kemmis (1985) already noticed, reflection is "action-oriented, social and political. Its 'product' is praxis (informed, committed action), the most eloquent and socially significant form of human action" (p. 139). A more detailed account on reflection perfectly matching the context of our study is provided by Johns (2000), who compares reflection with a window through which the practitioner can view and focus self within the context of his/her own lived experience in ways that enable him/her to confront, understand and work towards resolving the contradictions within his/her practice between what desirable and actual practice is. Through the conflict of contradiction, the commitment to realise desirable work and understanding why things are as they are, the practitioner is empowered to take more appropriate action in future situations.

In the context of the thisresearch, it is important to stress that teachers' reflections during the research can lead teachers to their personal and collective growth and, therefore, to change their unsustainable practices into more sustainable ones.

\section{Qualitative Phenomenological Approach to the Study}

In the field of ESD and also in mathematics education, qualitative methods are used quite extensively since they display the tacit knowledge that is hard to obtain through more objectivistic and quantitative means (Buttigieg \& Pace, 2013; Di Martino \& Zan, 2010; Pipere, Reunamo, \& Jones, 2010). Intepretative Phenomenological Analysis (IPA), 
currently widely used in the fields of health and psychology, is very new to education research, with only a couple of studies are available on teacher education and professional development using IPA (Bailey, 2011; Bainger, 2011; Bleiler, 2012). This study tries to search for the ways to bridge this gap using IPA in the field of mathematics teachers' professional development, focusing on their mathematical identity and further consequences on professional practice in the context of ESD. IPA sees the participants as experts atknowing about and describing their own experiences (Reid, Flowers, \& Larkin, 2005) and, in this way, helps to find out how individuals are perceiving the particular situations they are facing, how they are making sense of their personal and social world (Smith \& Osborn, 2008). Hence, IPA can be an ideal tool to use for a study in the field of education.

The methodological distinction between this study and quantitative research in the field of ESD or qualitative research that focuses directly on the assessment of educational content or pedagogical methods for ESD should be noticed. In this respect, our research draws on the phenomenological approach within a paradigm of critical constructivism (Goodman, 2008; Kincheloe, 2005) - a variety of social constructivism. Collaboration between the researcher and the teacher (co-researcher) during the interview, fostering self-reflection on the teacher's personal and professional development, allows for the creative organisation and navigation of process where the interviewee can independently arrive at constructing a unique critical discourse at personal, institutional, community and societal levels. For the researcher, it only remains to evaluate how close these reflections are to the essential principles of sustainability and formalised requirements for ESD competences.

One of the strengths of qualitative research, which is particularly beneficial for this study, is indirect and unobtrusive inquiry into the subjects' views on the research problem. Hence, the deep phenomenological interviews that elicit lengthy (in comparison with other methods) and deep self-reflection scale up the scientific rigour of this study in terms of credibility and confirmability (Lincoln \& Guba, 1985). If an experienced professional is allowed to reflect extensively and in detail on his/her life and professional activities, reacting to the researchers' incentives, he/she will reveal aims, meanings, values, content, competences, methods and an impact of this work on the interviewee, other people, his/her community, society etc. In this way, such interviews can be used to provide insight into the sustainability of teachers' personal and professional activities in social and institutional context.

In summary, the aim of this study is to explore the dialogical models of mathematic teachers' life-long relationships with mathematics, towards uncovering interactive patterns emerging between the teachers' mathematical identity and their perception of factors influencing the mathematical philia/phobia of their students in relation to ESD competences for educators. The analysis of qualitative data will help to find out the answers to the following questions: 1) What are the major features of interviewed mathematics teachers' mathematical identity?; 2) What kind of dialogical models emerge for making sense of mathematics teachers' mathematical identity in a life-long perspective?; 3) What interactive patterns can be observed between the mathematical identity of teachers and their perception of students' mathematical philialphobia? and 4) How do these dialogical models and interactive patterns align with the ESD competences for educators? 


\section{Method}

\section{Sampling}

A large number of participants is not necessary for IPA to obtain sensible data; consequently, three mathematics teachers, who are doctoral students doing research on mathematics education, were recruited for individual in-depth, semi-structured interviews. The search for the relevant research participants lead to these persons with a unique configuration of identities in relation to mathematics teaching, learning and research. Several other studies using IPA have been published using three participants (Bainger, 2011; Bates, 2012).

Smith and Osborn (2008) advise that an IPA sample should consist of relatively similar (homogeneous) cases rather than extremely different examples. So, first of all, the selection of gender was determined by the domination of women in mathematics teaching in Latvia. An overview of the participants' real-life experiences shows a similarity of the main facets of personal history being students enrolled in a mathematics enrichment class at school, university students at mathematics teacher education and training programmes, school teachers of mathematics and doctoral students in pedagogy. The aim of sampling was to recruit a purposive sample as opposed to a strictly representative sample. The results in this study represent the specific group of mathematics teachers and are not representative of all mathematics teachers in Latvia.

The first participant (a pseudonym - Ann) is a 45-year-old woman with a university diploma in secondary school mathematics/physics teaching. She is holding a master's degree in pedagogy. She has 10 years teaching experience at school and 3 years at the university level, as well as 8 years experience as a school principal. Ann has designed many in-service teacher education and training courses, and she is the co-author of textbooks on mathematics. The second participant (a pseudonym - Irene) is a 37 years old woman with a university diploma in teaching secondary school mathematics, physics and information technology (IT) and a master's degree in mathematics, specifically geometry. She has 17 years of teaching experience at school. The participant has been engaged in several European Unionprojects and gained recognition as one of the best elementary school mathematics teachers in terms of her students' achievements at national mathematics olympiads. The third participant (a pseudonim - Elsa) is a 37-year-old woman with a university diploma in elementary school mathematics and IT and a master's degree in pedagogy. She has a lengthy teaching experience of 15 years.

\section{Procedure and an Interview}

The participation in the interview was voluntary, anonymous, confidential and based on the written consent. The date, time and location of the interviews were arranged at the participants' convenience. An interview schedule was prepared prior to the interview, starting with a wider picture and then focusing on the details (Howitt, 2010). Specific open-ended questions reflecting the research objectives were generated on the basis of a review of the relevant literature. The main areas of interview schedule were the following: mathematics and its meaning to the participants (general context); doing mathematics: social, institutional and self-evaluation; relationships with mathematics in different social roles and mathematics philia and phobia in an educational context: concepts, causes, fostering and impeding factors (Appendix). Throughout the interviews, 
a process of probing was adopted, and the interviewer often requested further details to obtain rich accounts. All interviews were recorded on an audio recorder with the participants' permission and transcribed verbatim by the first author. The questions were flexibly adapted to the direction and pace of an interview for each participant.

The interviews were conducted by the first author of the paper, a female academic researcher at university while delivering a doctoral programmme $(n=2)$ and a teacher at school where one participant was working. The interviews lasted for between 67 and 90 minutes. The atmosphere during the interviews was open, friendly and motivating.

\section{Analysis}

IPA intends to explore how research participants experience their world and, consequently, provides an insider's perspective of the phenomenon under investigation. The rigorous analysis derives themes from the data itself, as opposed to categorising data on the basis of pre-determined categories or a priori assumptions (Dickson, Allan, \& O'Carroll, 2008). The analysis process for each transcript was based upon a model developed by Smith, Flowers and Larkin (2010): 1) reading and re-reading of transcription; 2) initial noting based on free associations using descriptive, linguistic and conceptual comments; 3) developing emergent themes and 4) searching for connections across emergent themes, considering subordination, contextualisation, numeration and a function of themes.

The three transcripts consist of 32,363 words in total. Initially, the first interview's transcript was analysed by the two researchers (the authors of this paper). During several readings, emergent comments on the semantic content and language were noted in the margins alongside the text. These notes were listed separately and searched for patterns, repetition or connections while creating a table of themes. The two researchers compared their findings and agreed upon a preliminary framework of themes and sub-themes. It is a common practice within IPA for an indepth analysis of a subset of interviews to form the basis for an analysis of the remaining transcripts (Adams, Rodham, \& Gavin, 2005). Therefore, both authors returned to the remaining transcripts and, guided by the preliminary framework, created an analysis of the two remaining interviews, including additional themes as required. Afterwards, the authors coordinated and finalised the analysis of the three interviews, looking for patterns across cases. Some progress was reviewed by both authors to ensure that there was an agreement between the thematic interpretations and their reflection in the teachers' personal narratives.

\section{Results and Discussion}

Alhough presentation of IPA results is usually based on emergent themes (Smith \& Osborn, 2008), in order to provide systematic answers on the four research questions, the further account will be structured in a more deductive way. The answers to each research question will be grounded on the emanated subthemes acknowledged as important by the researchers and illustrated with exact quotes from the interviews' transcripts (Howitt, 2010). It should be noted that, during the process of inductive analysis, the researchers were not guided by any preconceived categories or theoretical structures. The theoretical insights provided at the beginning of the paper were induced basing on the results of IPA. 


\section{The Mathematics Teachers' Mathematical Identity}

The major features of mathematics teachers' mathematical identity are displayed in line with a theoretically developed structure of mathematical identity: 1) relationships with mathematics; 2) competence and 3) social and institutional context.

Relationships with Mathematics. Following the study by Di Martino and Zan (2010), relationships with mathematics teaching and learning are analysed in a broader life context, highlighting their properties and emotional tone. For all the interviewed teachers, these relationships differed to some extent. In Ann's case, we observed the positive instrumental relationships with mathematics, using it as a lifebuoy in practical life situations that were atune with her general positive social and emotional orientation during the interview. In Irene's case, her love towards mathematics as a unique exclusive subject, positive relationships as well as instrumental relationships are apparent, though not so much as to helping in daily hassles, but as to developing the entire personality and, especially, cognitive processes.

... yet mathematics is a queen, and my great wish is to serve the queen, not to the science, just helping other sciences to process data or likewise. Mathematics is too beautiful to be just a supplementary aid, it is not enough to see it as conceived just for some practical purpose. (Irene)

As for Elsa, the instrumental relationship with mathematics is particularly strong, though. It serves more as a general coping strategy in life. Her overall emotional attitude towards mathematics is ambivalent and changing.

These perspectives coincide with the conclusions drawn by Kaasila et al. (2006) that different views about mathematics may be explained by the socially emotional orientation and coping strategies of research participants. Hence, the common theme for all three teachers was instrumental relationships with mathematics, although using it for different purposes: to solve professional and life situations, to develop cognitive skills and the entire personality or to aid as a psychological coping strategy. None of the teachers admitted to negative relationships with mathematics regardless of mentioned hardships while learning or teaching it.

Competence as learners and teachers of mathematics. Many authors (Anderson, 2007; Gee, 2001; Wenger, 1998) stress the main role of self-recognised and socially acknowledged competence as learners and teachers of mathematics in the construction of mathematics identity for teachers and students. Although the interviewer did not ask direct questions about the teachers' mathematical competence, an analysis of the transcripts reveal it as a very small detail, yet showing significant variations in this area. Di Martino and Zan (2010) observe patterns in the essays of students that lowly perceived competence often correlated with an instrumental vision of mathematics. Similar patterns are noticed in the teachers' interviews: those teachers whose answers revealed competence perceived comparatively lower focused their narratives on an instrumental vision of mathematics at a larger extent. Ann's answers show an alternating level of perceived competence: a solid confidence at primary school, some hardships with mathematics during secondary school and university, complemented with attempts to justify these hardships mainly by external factors (for instance, overly theoretical studies at university). The high level of self-recognised and socially acknowledged competence was noticed in 
Irene's narrative, dovetailing with her love for mathematics as an exclusive science. As for Elsa, it seems that her pattern somewhat matches with that of Ann, showing confidence at primary school and some problems at secondary school and university.

In primary school, I had a teacher who was very clear in her instructions. I had only the highest marks. The teacher explained to us (the material), and, probably, because of my auditory memory, I could literally repeat everything in an hour or three hours. Then the teacher changed, and we let things slide... I let my knowledge slide... (Elsa)

In this specific case of a vacillating level of competence, one can recognise the constant efforts to find some person or institution responsible for causing strong emotions.

Social and institutional context of learning and teaching mathematics. The societal attitude towards mathematics was evaluated by the interviewees as mostly negative since society views mathematics as a dry, unnecessary science disconnected with life. It seems that Irene's competence in mathematics allows her to set higher expectations towards a career in mathematics that has, yet, to be fulfilled because of the unsustainable status of mathematics as a fundamental science in Latvia and lack of economical benefits of a career in mathematics. She also emphasises the unsustainability in education caused by a negative economical situation that leads to extensive migration.

Each year, I see 2 or 3 pupils in every form to go abroad. Those who intend to leave do not plan to go deep in mathematics They think more about languages... Nowadays, thinking about mathematics is pointless... We need to think about how to raise the children abandoned by their parents (going abroad), and the majority of them will leave (the country) while at school or before or after university. (Irene)

In terms of the influence of the surrounding people, all teachers acknowledge a lack of their parents' restrictions regarding their professional choices. In Ann's and Elsa's cases, strong emotional and material support from family while completing an education is evident from time to time. In Ann's and Irene's stories, the personalities mentioned most often are teachers at school and lecturers at university; but for Elsa, it is her father who awakened her interest in mathematics during early childhood (Swennen et al., 2008).

I remember, when I was a child, we drove as a family around a lot (in a car). My father, all the time, proposed that I do mental arithmetics: if we are driving at $40 \mathrm{~km}$ per hour, how much do we have to increase our speed to get to your aunt's place or elsewhere in two hours? [...] I always had to ground and explain the invented result to him. (Elsa)

\section{Teachers' Mathematical Identity and Other Identity Voices: Dialogical Models}

To reveal what kind of dialogical models emerge for making sense of teachers' mathematical identity in a life-long perspective, we shall turn to 1) a dialogue between the identity voices of teachers; 2) interplay of the subject, didactics and pedagogical identity (Beijaard et al., 2000) and 3) the self-motive versus the other-motive and psychological functions of elicited themes. 
Dialogue between the identity voices. As the description of the sample shows, the participants had a lively bouquet of various sub-identities or identity voices. However, not all of them are reflected in the interviews, only the most salient voices surface and are elaborated in detail. For Ann, the most engaging dialogue is observable between her identities as a pedagogue and as a mathematics teacher, where a pedagogue's identity took a dominating role.

... but, really, I wanted to become a pedagogue, definitely. In what subjectthis could be played out differently. (Ann)

In all her identities, except the role of a school principal where mathematical skills help to deal with practical problems and view them from different angles, the emphasis is on non-mathematical aspects. To Ann, mastering mathematics is determined by responsibility towardslearners and a wish to feel secure and confident as a teacher.

Irene stressed her desire to study mathematics at university; the pedagogical subjects in the teacher education and training programme were just a supplement to the serious mathematical courses. Her main identity voices, intertwined in a balanced dialogue, were the voices of a mathematics teacher and a mathematician. In terms of social identity theory (Turner, 1982), both Ann and Irene as mathematics teachers show notable ingroup favouritism of taking pride in their identification with mathematics teachers whom they perceive as an elite subgroup of teachers. Stronger in-group favouritism is observed in Irene's case, who cares both for the image and future of mathematics teachers and is proud of mathematics teachers of her town in the times of insecurity and threat (Voci, 2006).

Speaking about the mathematics teachers' level of knowledge, they are elite, they know very much, they have studied a lot -2-3 times more than all other teachers, and, now, at schools they work 2-3 times more than other teachers because to prepare for mathematics lessons is harder than to prepare for, let's say, sports.

Because of a few ignorant teachers, all teachers have been scolded. For a long time, I could not understand why mathematics teachers have been criticised (in Latvia). When attending teachers' professional courses, I suddenly realised that the mathematics' teachers of our town and those coming from rural areas are two absolutely different worlds. And I do not know how to change it because nobody wants to work as a mathematics teacher in the country. (Irene)

As for Elsa, her sub-identities as a teacher and a doctoral student are entangled with deeply hidden voices of family members and women. She acknowledges her extensive quest before arriving at her current identity: initial rejection of the teaching profession, changes in professional choices (i.e., psychology, forensic medicine, teacher of chemistry and physics, teacher of IT) and experimenting with teaching elementary grades before realising that she wishes to work at primary school. Possibly, because of this quest, her identity of a mathematics teacher is not so salient and pride-evoking as it is for Ann and Irene.

Interplay of subject, didactics or pedagogical identity. The identity voice similarly important for all the interviewees was their professional identity pertaining to core 
teaching aspects such as the subject matter, didactics and pedagogical expertise (Beijaard et al., 2000). For Ann, the prevalence of pedagogical and didactics expertise depicts the dominating position of her identity as a teacher.

... However, that can be with mathematics, but we need to see that we teach a person. And the teacher needs to be so intuitively wise so as not to miss the moment when mathematics becomes unattainable for the person. The person can master some basic knowledge in this field, but you should not tear him/ her down to reach more. Maybe helshe will be able to deal with it somehow differently. And, maybe, this way, we would make his/her life cooler. (Ann)

In Irene's case, the internal dialogue between the mathematician and the teacher of mathematics leads towards the expertise in the subject matter as a core aspect of her teaching, especially evident in her successful preparation of pupils for the mathematics olimpiads. For Elsa, her emerging teacher's identity in professional terms was mostly grounded on her ideas for changing teaching methods, thus designating her expertise in didactics.

Self-motive versus the other-motive and psychological functions of themes. This facet of dialogical models is the most individualised, showing the psychological commonalities and differences of participants. Some linguistic features discovered in the narratives will also be compared to provide a hint about the personality of each teacher.

The prevalence of the other-motive over the self-motive eliciting mostly positive feelings is observed in Ann's answers. The themes elicited from her answers are regarded as self-defense from some failures in mathematics at school and university, boosting the teachers' self-esteem as well as showing a high level of responsibility and hiding insecurity in front of her students while expressing empathy towards them, probably caused by the ability to put herself in their situation. The terms and expressions she used most often are saturated with compliance and immersion (i.e., "a little bit", "sniff it out", "to work it through", "to dig it out"). As for the use of pronouns, the usage of "we" dominates over the usage of "you", while "I" is applied more seldom than in the answers from other teachers, also stressing the other-motive.

In Irene's case, her self-motive, which is exposed in her strive for constant selfdevelopment, is well-balanced with the other-motive (identification with mathematics teachers, care for children's future lives etc.). However, if the self-motive elicited mostly positive feelings, the other-motive produced the ambivalent affection that is discernible in the psychological functions of her themes. In these themes, in the same manner as Ann, Irene boosts her self-esteem by reflecting on her past achievements, but her disappointed mood is revealed in her disillusionment about the educational system and economical benefits of the chosen discipline and in her critique of conservative teachers and administration avoiding the self-development and intolerance towards lazy learners. The term used more often was "tricky", while the use of the pronoun "I" dominated over the use of the pronoun "we".

In turn, Elsa's self-motive dominates over her other-motive, and both motives arouse ambivalent feelings. The themes noticed in her reflections, even to a greater degree in comparison with Ann, serve as self-defense as for her failure of mathematics at school and university, though sticking to external attribution. Similary, as in Ann's and Irene's cases, this helped her to build up her self-esteem; only in her case, it is with the help of 
external factors. Elsa's other-motive is significantly dominated by the critique of her own teachers, both the educational system in general and some specific aspects of it. However, the positive relationship with her father, taking pride in a "top level" commission on the graduation examination, "showing off" her mathematical skills in front of handsome boys at school and helping a lawyer to solve a simple mathematical problem disclosed the masculine and power-related discourse of her identity construction process. Such terms as "awful/awfully" and "dear" when addressing somebody were used quite often, and, similarly as in Irene's case, the usage of "I" dominated over the usage of "we" and "you".

The relationships between the self-motive and the other-motive can be included in a list of features to illustrate a person's orientation towards sustainability, and it seems that a permanent domination of the self-motive would lead to unsustainable relationships with the surrounding world and specific areas of knowledge. According to Linde (1993), defending one's self through explanations is an important part of any type of autobiography. Kaasila et al. (2006) found that the largest number of explanations in stories of pre-service teachers regress to negative views of mathematics. Although none of the interviewed teachers expressed a negative view of mathematics, as in the study by Kaasila et al. (2006), we encountered a lot of explanations as well as critical views.

\section{Teachers' Mathematical Identity and Their Perception of Students' Mathematical Philia/ Phobia: Looking for Interactive Patterns}

The non-traditional aspect of the analysis was the cross-checking for the coherence or collisions between the teachers' mathematical identity and the way they see mathematical philia and phobia in their students. For each teacher, we shall define their pedagogical "slogan", the main approaches to deal with the mentioned issue, possible causes for these approaches found in their past experience and a direction of their critique.

Ann's pedagogical 'slogan' sounds like this: The key value - a person, not mathematics. She sticks to a humanistic approach (freedom, avoiding pressure, respect for diversity, humane attitude, dignity, responsibility for the learners' path of life, pedagogical optimism, cautious teaching methods) and instrumental interpretation of mathematics and its teaching methods (practical applicability in life, a career, gradualness/a spiral approach), not to the excellence in mathematics at any cost. Ann feels great satisfaction from pedagogical work and being accepted as she is.

In the morning, I go to the class in total turmoil and with conflicts inside, and then, in a moment, I see the children, and all these conflicts fade away and in three minutes. I do no recall any of the things that bothered me. I have this specific situation, all these specific people who need me exactly as I am and everything happens. (Ann)

She votes for stability, consistency in teaching and suggests that greater efforts can gradually build the learners' motivation.

The roots of this approach can be traced back to the very friendly classmates at school, sincere and understanding teachers at school and university as well as the fact that she was not forced to choose mathematics for her career or to master mathematics at a high level. This approach coincides with her positive instrumental relationships 
with mathematics and general positive socially emotional orientation. Since Ann encountered some trouble with mathematics at school and university, it is more natural for her to feel empathy towards all learners having some problems with mathematics. With a dominating teacher's identity (and) having strong didactical and pedagogical expertise, she lays emphasis on her pupils's achievements as well as on their life quality, not that much on the subject matter. At the same time, she suggests the gradualness and placing efforts in dealing with mathematical tasks as she admits her own fighting spirit and perseverance dealing with hardships. Ann is strongly convinced about mathematics as a subject securing the learners' future life and takes pride in her ability to use mathematics in different identity positions (working as a principal, a teacher at school, university, writing textbooks etc.). Her answers do not contain the pupils' critique, while the required performance of teachers is described at length.

Irene's pedagogical message can be regarded as a self-actualisation, achieving success through hard work. She lays emphasis on continuous educators' self-development, individual learners' psychological peculiarities, the roles of surrounding people, hard work and perseverance. Although she admits that the main goal of education is to find oneself, not necessarily to master mathematics, her own success has been connected with her love towards mathematics, overcoming the difficulties and reaching a high competence in it. Irene discerns the causes of mathematical phobia related to both internal factors (learning difficulties, laziness, lack of regular practice, a wish for immediate results etc.) and external factors (learning for exams or for parents, parents' hindrance of children's self-esteem in mathematics etc.). To ensure philia of mathematics, Irene suggests perceiving mathematics as a hobby. Regarding the teacher's performance, she lays emphasis on clear instructions and a positive attitude towards children, a need to instill love of mathematics in her pupils (Rameau \& Louime, 2007).

Irene's expertise as a mathematics teacher is high, and her life story is interspersed with challenges and the thrill of overcoming difficulties with mathematics, creating a kind of addiction to success.

If you succeed in mathematics, your psychology changes. You want to reach the same outcome again, then even a more significant one, then you understand that you change. Probably, mathematics changes the entire person, his/her way of thinking, the whole process of thinking. The first time success in an olympiad or some difficult test make you think that you are special and that not everybody can do this, and this self-confidence changes your life. (Irene)

Changes in her self-esteem and the entire personality have occured not only through hard work and accomplishments, but also because of her openness, curiosity and a critical mind. Pupils' and their parents' as well as other mathematics teachers' critique is noticeable in the texture of Irene's answers, though the teacher's positive input is emphasised more.

The major challenge observable in Elsa's life story is a matter of attribution of achievements and failures in mathematics. Are they caused by external or internal factors? She calls for radical changes in the Latvian educational system/structure, ensuring the adequate function of both external factors (parental influence, material resources, standards etc.) and internal factors (the development of learners' cognitive strategies, a possibility to use mathematics to deal with real-life problems etc.). Unlike Irene, Elsa does not speak so much about the necessary changes in teachers and herself. The main 
transformational emphasis is on the factors external to her as a person or the entire professional group of teachers, protecting her self-motive. Speaking about pupils' learning, she looks at cognitive factors, such as thinking strategies, discovery approaches, development of algorithms, from an affective point of view. She also talks about a rising interest towards the application of mathematics in real life, such as taking pleasure in doing sums, developing a humane attitude, as well as an opportunity for the learner's individual expression. She also criticises parents for their influence on pupils' external motivation and for attribution of their children's failure to heredity, overemphasising the fourth face of mathematical identity - nature (Anderson, 2007).

I wonder how it is possible that a parent can come to me and, in front of her child, announce, "You know, I have never understood mathematics, and my child will not understand it." And the child sits there and listens, and he is given the green light not to understand mathematics because of his mother. And, then, I am telling her, "Imagine, you will need to look for a special school for your grandchildren since learning difficulties will progress, not regress, with each generation. (Elsa)

In Elsa's case, it is evident that her tale about the love of mathematics in childhood because of her father and her disappointment later in life at not beening able to restore these loving relationships at the same rate call for some explanation and defence. She actively criticises her teachers, her pupils' parents, the school environment; she is probably instinctively aware of her own difficulties with mathematics. However, she is quite approving towards her father's individualised, but authoritarian pedagogical approach, as it formed her strategies of logical thinking and fostered her love of arithemtics. In her work with learners, she is trying to mould similar strategies, speaking in favour of rather individualised approaches. Elsa' answers contain a critique of diverse factors external to the teacher: pupils, parents, school system etc.

\section{Dialogical Models and Interactive Patterns: Alignment with the Competences for Educators in ESD}

To see how the revealed dialogical models of teachers' identity and their pedagogical theories align with the educators' competences in ESD, we examined the detailed table of educators' competences (UNECE, 2011) and summarised the parts and elements of table corresponding to the approaches explicitly or implicitly encountered in the interviews. Eventually, the three teachers' approaches coincide with the third feature of ESD, namely, achieving transformation in teachers, learners, pedagogy and educational systems. The strongest association with this feature is noticed in Ann's humanistic theories and Elsa's critical outlook for unsustainability around her. It is observed in Irene's subject-oriented pedagogy. In the text, the competences, as included in the UNECE document, are italicised.

All three teachers, from the position of critically reflective practitioner, both in their dialogical models of identity and pedagogical mentality, enounced how engagement in real-world issues enhances learning and makes difference in practice.

We need to do it a little bit differently. There should be some real possibility to apply what you know, a possibility to direct your mathematical knowledge 
to be able to engage in some entrepreneurship and mathematically calculate your business activities. We (as society) lack this initiative ... to be responsible for something from the beginning to the end. (Ann)

Several competences for ESD were exposed by two of the teachers: for instance, both Ann and Elsa show understanding of a need to transform the way we educatel learn and demonstrate their attempts to facilitate participatory and learner-centred education that develops critical thinking and active citizenship.

I have a very good game related to the theory of probability that grounds the games of chance ... [describes the collective game with candies]. And pupils are so extremely excited about this game, and they say, "Thank you, teacher, for this lesson. Now I shall not buy lottery tickets at all!". Afterwards, we work on this theory of probability, and children grasp it easily. They are interested. They come to me with single-handedly calculated enormous figures, and they are so delighted: teacher, can you imagine such a probability! (Elsa)

In her answers, Ann revealed the importance of building on the experience of learners as a basis for transformation, perceiving herself as a facilitator and a participant in the learning process when she told about her learning together with her pupils at school and students at university. As it was already mentioned, her interactive pedagogical model emphasised the necessity for the engagement with learners in the ways that build positive relationships more often than the two other teachers. As for Ann's point of view in the context of ESD is concerned, it can be stated that such an approach does not reach beyond the anthropocentric horizon of humanity as an ultimate aim; however, the social orientation - all for humans - could serve as an initial point of sustainability, which is clearly better than pure selfishness or egocentrism (Salite \& Pipere, 2006). Possibly, overall respect towards external entities, in this case another person, will lay the foundation for reaching the aims of sustainable development to ensure an individual's qualitative and sustainable interaction with the social, cultural and natural world.

Elsa's answers, in their turn, contained a strong wish to challenge assumptions underlying unsustainable practice. Synthesising her approach, it should be admitted that search for unsustainabe practices and active critique of the surrounding world are positive goals to encourage further development, but only if we are able to complement this with adequate self-analysis, self-criticism and a quest towards the changes in ourselves.

In Irene's case, we also found a stronger social orientation and motivation to make a positive contribution to other people and their social and natural environment, both locally and globally, which is included in the section of ESD competences related to envisioning change. In general, the interviewed teachers want to transform something or somebody. Their transformations implicitly suggested the aim of mastering the subject to use it in life or to develop specific skills or even a mathematician personality; however, the meta-content or meta-message (Salīte, Gedžūne, \& Gedžūne, 2009; Sund \& Wickman, 2011) regarding sustainability are not so evident. 


\section{Conclusions}

In this paper, we have presented an extensive qualitative study aimed to explore mathematics teachers' mathematical identity by utilising dialogical models of teachers' relationships with mathematics. Interactive patterns emerged between this identity and teachers' perception of factors influencing the mathematic philia/phobia of their students. These models and patterns are also explored in relation to the competences for ESD educators in order to verify possible evidence of these competences in the answers from teachers as a meta-content implicated in motivations, valuesand main discourses.

We summarised the findings in relation to each research question framed as much as possible for a phenomenological study valued for the richness of specific details. Each question and its interpretation can serve as a foundation for further inquiry to be based. The common theme of teachers' mathematics identity was their instrumental relationships with mathematics using it to solve their professional and life situations, to develop cognitive skills and the entire personality or to aid as a psychological coping strategy. As nuanced as they were, none of the answers expose clear negative relationships with mathematics notwithstanding the diferences in the obtained level of competence. However, competence preceived comparatively lower is related to the instrumental vision of mathematics to a large extent. In general, a generally negative societal attitude towards mathematics and a positive impact of the family and surrounding people on the choices, interests and the teachers' identity development were reported.

The dialogical models, emerged in relation to the teachers' mathematical identity, show how different life experiences can lead to different identity voices surfacing in the interviews: for one teacher it was a domination of a pedagogue's identity over the identity of a mathematics teacher; for another, it was a balanced dialogue between the voices of a mathematics teacher and a mathematician while, in the third case, we can speak about the sub-identities of a teacher and a doctoral student entangled with several other hidden voices. The interviews also contain striking in-group favouritism of mathematics teachers, taking pride in their self-identification with this specific group perceived as an elite subgroup of teachers. The most salient identity voices guiding the dialogical processes become apparent as the priorities in the area of teachers' professional expertise: one teacher appears to be an expert in pedagogy and didactics, another - in the subject matter and the other - in didactics. Interestingly enough, the accounts of the three teachers contain all possible variations of relationships between the other-motive and the self-motive. For the placidly-oriented expert in pedagogy and didactics, the prevalence of the other-motive over the self-motive elicited mostly positive feelings. For the subject expert, with her strive for self-development, the self-motive was balanced with the othermotive, and the self-motive elicited mostly positive feelings while the other-motive elicited contending passions. For the didactics expert, with a strong inclination towards selfdefence, the self-motive dominated over the other-motive arousing ambivalent feelings. These uncommon entanglements ask for a deeper investigation although we already could question the sustainability of the dominance of the self-motive for the teacher. As in several other studies (Bainger, 2011; Kaasila, 2007), this study also reveals a serious drive towards defending the self through explanations. Furthermore, the elaboration, orientation and content of these explanations differed in each account.

The patterns displaying the interaction of the teachers' mathematical identity and their perception of learners" mathematical philia/phobia included, for instance, a 
humanistic approach and their instrumental interpretation of mathematics and its teaching methods as practised by the teacher with expertise in pedagogy and didactics having a dominating teacher's identity, the other-motive and positive affective orientation. She did not emphasise mathematics as the development of motivation and life quality of the learner so much and kept avoiding serious critique towards any subject, yet, still, illustrating the required professionalism of teachers.

The life story of the other teacher is full of excitement and explanations of challenges dealing with difficulties in mathematics and arriving at success that requires relentless development to reach. Being a mathematician deep in her heart and having strong expertise in the subject matter, she summons towards self-actualisation of achieving success through hard work, stressing the need for an educator's continuous self-development and knowledge of students' individual psychological peculiarities. Although she affords to critique upils, parents and teachers of mathematics, the positive input of teachers is also recognised.

As for the third teacher, she struggles with the dilemmatic issue of attribution of failure in mathematics either to external or internal factors. It is especially hard for her because of her emergent mathematics teacher's identity that tries to find its place among the other identity voices, with dominance of the self-motive and a lower perceived level of mathematical competence. After all, positioning herself as an expert in didactics, she deviates from the required changes in mathematics teachers or herself as a teacher by actively and elaboratedly criticising and calling for transformation of the factors that are external for her or her current professional group, such as her own teachers, pupils, parents and the school environment.

The hallmarks embedded in the biographical reflections of experienced teachers show partial alignment between the dialogical models and the interactive patterns found in the accounts of teachers and competences for educators in ESD mandated by UNECE. Remarkably, all three teachers emphasised the sole feature of ESD competences for teachers: achieving transformation in educators, pedagogy and educational systems in all aspects of learning to know, learning to do and learning to be (UNECE, 2011). As critically reflective practitioners, they all reported the connections between knowledge and its practical application for life issues and acknowledged their wish to transform education, facilitate participatory and learner-centred education towards developing higher-order thinking. Some of the teachers reported on the transformation based on their experience as learners, perceiving themselves as facilitators and participants in the learning process. Moreover, positive relationships with learners, challenging assumptions that underly unsustainable practice and motivation to make a positive contribution to other people were noticed. All in all, the life experiences of all interviewed teachers created the transformative disposition of their mathematics identity although, in the context of sustainability, this disposition lacks the meta-orientation towards higherorder goals rising above mastering the subject matter as a simple tool to improve one's own life and oneself. Among others, one strength of this qualitative research could be its tactical and catalytical authenticity (Guba \& Lincoln, 1989), envisaging that engagement in extensive collaborative professional reflection could lead to the teachers' personal and collective growth and, therefore, to changes in teachers' practices.

We conclude with a reflection on the limitations of the present study. They include: 1) a small sample that is typical for IPA studies and, therefore, the contextual nature of obtained data; 2) situational bias related to the emotional and cognitive context of the 
teacher on the day of the interview; 3) social desirability or wish to present themselves in a more positive light to the researcher; 4) some psychological issues (for instance, self-esteem, personal and professional insecurities) impinge on the content and form of participants' verbal expressions during the interview (Bainger, 2011). However, at least in terms of generalisation, it is not a serious issue as IPA does not claim to create general or grand theories (Smith et al., 2010). One more limitation, especially visible in the case of IPA, concerns the fact that the analysis of the results is influenced by "the researcher herself; her own experiences in the field, her beliefs, biases, tolerances, prejudices, preconceptions and motivations" (Bainger, 2011, p.33). This issue was partly dealt with by using the integrative point of view from two independent researchers during the data analysis and interpretation. Due to space constrains, only some of the most important facets of analysis and quotes from the interviews are included in this paper.

To use the qualitative study in other contexts, replication needs to be wisely adapted to the local circumstances The results of this study provide some implications for practice, at least on the Latvian scale. Initially, implementers of the ESD competences for teachers would utilise already existent aspects of transformation, within any sphere of educators' competence, as the grounds for implementation of two other features: a holistic approach and envisioning change. Strong in-group favouritism of mathematics teachers would be a good sign for the educators of future mathematics teachers to recrute new students into these programmes, demonstrating excellent professional role models and attesting to the high professional status of mathematics teachers. Teachers' pedagogical theories explaining students' mathematical phobia and philia can be used by designers of teacher education programmes and by mathematics teachers' educators to show future teachers the potential diversity of approaches and emphasise their explicitly contextual nature. To conclude, these findings state a suggestion for educational philosophers and politicians to consider an apropriate immediate aim for all stakeholders in education in order to enhance its share in the sustainable future. Another option would be to stress the importance of specific areas of knowledge in order to create a sustainable society and realise an individual learner's achievements in a particular area as a prerequisite of personality development.

This study calls for further research using the theory of dialogical self in the area of teacher education and empirically observing the correspondence between the existing competences of teachers and the ESD competences constructed by UNECE, which seem more like an ultimate aim to be adapted for the current situation. This area needs a more profound and detailed research, employing also quantitative approaches to grasp the ways in which teachers' mathematical identity can influence their students' mathematical identity and, ultimately, not only their achievements in mathematics, but also their life skills, cognitive strategies and the development of personality. It would be useful to conduct further research to reveal and compare the general attitude towards mathematics in different social groups not connected with mathematics in their professional or daily activities. Another avenue of inquiry is the integration of ESD competences in in-service and pre-service teacher education programmes on local and global levels.

Transformation is not an easy job and asks for the right tools and proper virtues. Stinson (2009), in his qualitative self-reflective dissertation about the mathematics teachers' journey of identity construction, stresses the power of self-examination in constructing his identity and points to the "humility, desire, courage, and honesty necessary for change" (Stinson, 2009, p. 5). Ultimately, this study is not so much about grasping 
some school subject's content as about our prospects to reach sustainability during our lives in the immediate and distant future, or not at all. Yet, we would like to ask: What kind of teacher would you choose to master mathematics with?

\section{References}

Adams, J., Rodham, K., \& Gavin, J. (2005). Investigating the "Self" in deliberate selfharm. Qualitative Health Research, 15(10), 1293-1309.

Anderson, R. (2007). Being a mathematics learner: Four faces of identity. The Mathematics Educator, 1, 7-14.

Ashcraft, M. H. (2002). Math anxiety: Personal, educational, and cognitive consequences. Current Directions in Psychological Science, 11(5), 181-185.

Bailey, S. (2011). Taking up the challenge: An interpretive phenomenological analysis of teachers' perceptions regarding the presence of asylum seeker and refugee pupils (ASR) within mainstream primary schools in the Midlands, and the implications this may hold for educational psychologists practice (Unpublished doctoral dissertation). The University of Birmingham, Birmingham, the United Kingdom.

Bainbridge, J. M., \& Macy, L. (2008). Voices: Student teachers link teacher education to perceptions of prepardness[sic] for literacy teaching. Teacher Education Quarterly, $35(2), 65-83$.

Bainger, L. (2011). Giving teachers a voice: Using interpretative phenomenological analysis in music education research. Music Education Research and Innovation, 14(1), 32-39.

Bates, E. (2012). The transformative power of learning: An interpretative phenomenological analysis of the learning experience of apprentices. In Proceedings of the International Academic Conference (pp. 96-113). Prague: International Institute of Social and Economic Sciences.

Beijaard, D., Verloop, N., \& Vermunt, J. D. (2000). Teachers' perceptions of professional identity: An exploratory study from a personal knowledge perspective. Teaching and Teacher Education, 16, 8-23.

Bikner-Ahsbahs, A. (2003). A social extension of a psychological interest theory. In N. A. Pateman, B. J. Dougherty \& J. Zilliox (Eds.), Proceedings of the 27th Conference of the International Group for the Psychology of Mathematics Education (Vol. 2, pp. 97-104). Honolulu: College of Education, University of Hawaii.

Bleiler, S. K. (2012). Team-teaching experiences of a mathematician and a mathematics teacher educator: An interpretative phenomenological case study. Retrieved November 5, 2013, from http://scholarcommons.usf.edu/cgi/viewcontent.cgi? article $=5176 \&$ context $=$ etd

Brown, T., Jones, L., \& Bibby, T. (2004). Identifying with mathematics in initial teacher training. In M. Walshaw (Ed.), Mathematics education within the postmodern (pp. 161-179). Greenwich, CT: Information Age Publishing, Inc.

Browne, M. E. (2009). A sociocultural study of mathematical and other identities of "struggling" teenager boys (Unpublished doctoral dissertation). The University of Exeter, Exeter, the United Kingdom.

Buttigieg, K., \& Pace, P. (2013). Positive youth action towards climate change. Journal of Teacher Education for Sustainability, 15(1), 15-47. 
Darragh, L. (2013). Sticking with it or doing it quickly: What performances do we encourage in our mathematics learners. In V. Steinle, L. Ball \& C. Bardini (Eds.), Mathematics Education: Yesterday, Today and Tomorrow. Proceedings of the 36th Annual Conference of the Mathematics Education Research Group of Australasia (pp. 218-225). Melbourne, VIC: MERGA.

Dewey, J. (1933). How we think: A restatement of the relation of reflective thinking to the educative process. Chicago, IL: Henry Regnery Co.

Dickson, A., Allan, D., \& O’Carroll, R. E. (2008). Biographical disruption and the experience of loss following a spinal cord injury: An interpretative phenomenological analysis. Psychology and Health, 23, 407-425.

Di Martino, P., \& Zan, R. (2010). 'Me and maths': Towards a definition of attitude grounded on students' narratives. Journal of Mathematics Teachers Education, $13(1), 27-48$.

Dobozy, E. (2012). Failed innovation implementation in teacher education: A case analysis. Problems of Education in the $21^{\text {st }}$ Century, 40, 35-44.

Domino, J. (2009). Teachers' influences on students' attitudes toward mathematics. Research and Teaching in Developmental Education, 26(1), 32-54.

Esmonde, I. (2009). Ideas and identities: Supporting equity in cooperative mathematics learning. Review of Educational Research, 79(2), 1008-1043. doi: 10.3102/ 0034654309332562

Fien, J. (2003). Education for a sustainable future: Achievements and lessons from a decade of innovation, from Rio to Johannesburg. International Review for Environmental Strategies, 4(1), 5-20.

Finlay, L. (2008). Reflecting on reflective practice. Retrieved April 22, 2014, from http:/www.open.ac.uk/opencetl/files/opencetl/file/ecms/web-content/Finlay(2008)-Reflecting-on-reflective-practice-PBPL-paper-52.pdf

Gee, J. P. (2001). Identity as an analytic lens for research in education. Review of Research in Education, 25, 99-125.

Gerretson, H., Howes, E., Campbell, S., \& Thompson, D. (2008). Interdisciplinary mathematics and science education through robotics technology: Its potential for Education for Sustainable Development (A case study from the USA). Journal of Teacher Education for Sustainability, 10(1), 32-41. doi: 10.2478/v10099-0090023-4

Goodman, G. S. (2008). Coming to critical constructivism: Roots and branches. In G. S. Goodman (Ed.), Educational psychology: An application of critical constructivism (pp.33-52). New York, NY: Peter Lang.

Guba, E. G., \& Lincoln, Y. S. (1989). Fourth generation evaluation. Newbury Park, CA: Sage Publications.

Hannula, M. S. (2002). Attitude towards mathematics: Emotions, expectations and values. Educational Studies in Mathematics, 49(1), 25-46.

Hawley, T., Crowe, A., \& Brooks, E. (2012). Where do we go from here? Making sense of prospective social studies teachers' memories, conceptions, and visions of social studies teaching and learning. Teacher Education Quarterly, 39(3), 63-83.

Hembree, R. (1990). The nature, effects, and relief of mathematics anxiety. Journal for Research in Mathematics Education, 21(1), 33-46.

Hermans, H. J. M. (1991). The person as co-investigator in self-research: Valuation theory. European Journal of Personality, 5(3), 217-234. 
Hermans, H. J. M., \& Dimaggio, G. (2004). The dialogical self in psychotherapy. Hove: Brunner-Routledge.

Hermans, H. J. M., \& Hermans-Jansen, E. (1995). Self-narratives. The construction of meaning in psychotherapy. New York: The Guilford Press.

Hermans, H. J. M., \& Hermans-Konopka, A. (2010). Dialogical self theory: Positioning and counter-positioning in a globalizing society. Cambridge: Cambridge University Press.

Howitt, D. (2010). Introduction to qualitative methods in psychology. Harlow: Prentice Hall.

Humphrey, M., \& Hourcade, J. J. (2009). Special educators and mathematics phobia: An initial qualitative investigation. Clearing House, 83(1), 26-30. doi:10.1080/ 00098650903267743

Illeris, H. (2012). Interrogations: Art, art education and environmental sustainability. International Journal of Education through Art, 8(3), 221-237. doi:10.1386/ eta.8.3.221_1

Insook, C. (2009). Korean teachers' perceptions of student success in mathematics: Concept versus procedure. Montana Mathematics Enthusiast, 6(1/2), 239-255.

Johns, C. (2000). Becoming a reflective practitioner. Oxford: Blackwell Science.

Jonāne, L. (2008). The didactical aspects of integrated natural science content model for secondary school education. Journal of Teacher Education for Sustainability, 9(1), 45-57. doi: 10.2478/v10099-009-0018-1

Kaasila, R. (2007). Mathematical biography and key rhetoric. Educational Studies in Mathematics, 66, 373-384.

Kaasila, R., Hannula, M. S, Laine, A., \& Pehkonen, E. (2006). Autobiographical narratives, identity and view of mathematics. In M. Bosch (Ed.), Proceedings of the Forth Congress of the European Society for Research in Mathematics Education (pp. 215-224). Sant Feliu de Guixols: Fundemi IQS - Universitat Ramon Llull.

Kaplan, A., \& Flum, H. (2012). Identity formation in educational settings: A critical focus for education in the 21st century. Contemporary Educational Psychology, $37(3), 171-175$.

Kemmis, S. (1985). Action research and the politics of reflection. In D. Boud, R. Keogh \& D. Walker (Eds.), Reflection: Turning Experience into Learning (pp. 139-141). New York: Kogan Page Ltd.

Kincheloe, J. L. (2005). Critical constructivism primer. New York: Peter Lang Publishing. Kinnvall, K. (2004). Globalization and religious nationalism: Self, identity and the search for ontological security. Political Psychology, 25(5), 741-767.

Larrivee, B. (2000). Transforming teaching practice: Becoming the critically reflective teacher. Reflective Practice, 1(3), 293-307.

Ligorio, M. B., \& Cesar, M. (Eds.). (2012). Interplays between dialogical learning and dialogical self. Information Age Publishing, Inc. Charlotte, NC: IAP - Information Age Publishing.

Lincoln, Y. S, \& Guba, E. A. (1985). Naturalistic inquiry. Beverly Hills, CA: Sage. Linde, C. (1993). The creation of coherence. New York: Oxford University Press.

Martin, D. B. (2007). Beyond missionaries or cannibals: Who should teach mathematics to African American children? The High School Journal, 91(1), 6-28. 
Katzschner, T. (2011). ESD to ESF (Education for Sustainable Development to Education for a Sustainable Future). In J. Newman \& P. Robbins (Eds.), Green education: An A-to-Z guide (pp. 160-166). Thousand Oaks, CA: SAGE Publications, Inc.

Nyamekye, F. (2010). Embracing mathematics identity in an African-Centered school: Construction and interaction of racial and mathematical student identities (Unpublished doctoral dissertation). University of Maryland, College Park, the US.

Pan, W., \& Tang, M. (2004). Examining the effectiveness of innovative instructional methods on reducing statistics anxiety for graduate students in the social sciences. Journal of Instructional Psychology, 31(2), 149-159.

Pipere, A. (2003). Identity of learning teacher: Examining structural variations and interactive "self". The Irish Journal of Psychology, 24(3 -4), 143-160.

Pipere, A., Reunamo, J., \& Jones, M. (2010). Perceptions of research in education for sustainable development: An international perspective. Discourse and Communication for Sustainable Education, 1(2), 5-24.

Rameau, P., \& Louime, C. (2007). Mathematics phobia: Are the mathematical sciences a pothole in the road of life? Current Science, 93(11), 1481-1482.

Reid, K., Flowers, P., \& Larkin, M. (2005). Exploring lived experience. The Psychologist, 18(1), 20-23.

Renert, M. (2011). Mathematics for life: Sustainable mathematics education. For the Learning of Mathematics, 31(1), 20-26.

Reunamo, J., \& Pipere, A. (2011). Doing research on education for sustainable development. International Journal of Sustainability in Higher Education, 12(2), 110 124. doi: $10.1108 / 14676371111118183$

Salite, I., \& Pipere, A. (2006). Aspects of sustainable development from the perspective of teachers. Journal of Teacher Education and Training, 6, 15-32.

Salīte, I., Gedžūne, G., \& Gedžūne, I. (2009). Educational action research for sustainability: Seeking wisdom of insight in teacher education. Journal of Teacher Education for Sustainability, 11(2), 14-30. doi: 10.2478/v10099-009-0037-y

Sangani, H. R., \& Stelma, J. (2012). Reflective practice in developing world contexts: A general review of literature and a specific consideratio of an Iranian experience. Professional Development in Education, 38(1), 113-129.

Sánchez, J. (2011). Teaching geography for a sustainable world: A case study of a secondary school in Spain. Review of International Geographical Education Online, $1(2), 158-182$.

Schon, D. A. (1983). The reflective practitioner. New York: Basic Books.

Sfard, A., \& Prusak, A. (2005). Telling identities: In search of an analytic tool for investigating learning as a culturally shaped activity. Educational Researcher, 34(4), 14-22.

Sims, L., \& Falkenberg, T. (2013). Developing competences for education for sustainable development: A case study of Canadian faculties of education. International Journal of Higher Education, 2(4). Retrieved from http://www.sciedu.ca/journal/index.php/ ijhe/article/view/3318/1965

Smith, J. A., \& Osborn, M. (2008). Interpretative phenomenological analysis. In J. A. Smith (Ed.), Qualitative psychology: A practical guide to research methods (pp. 53-80). London: Sage.

Smith, J. A., Flowers, P., \& Larkin, M. (2010). Intepretive phenomenological analysis: Theory, method and research. London: Sage. 
Stinson, A. B. (2009). An autoethnography: A mathematics teacher's journey of identity construction and change. Retrieved October 10, 2013, from http://scholarworks.gsu. edu/cgi/viewcontent.cgi? article=1042\&context=msit_diss

Sund, P., \& Wickman, P. O. (2011). Socialization content in schools and education for sustainable development - I. A study of teachers' selective traditions. Environmental Education Research, 17(5), 599-624. doi: 10.1080/13504622.2011.572156

Swennen, A., Volman, M., \& van Essen, M. (2008). The development of the professional identity of two teacher educations in the context of Dutch teacher education. European Journal of Teacher Education, 31(2), 169-184. doi: 10.1080/ 02619760802000180

Turner, J. C. (1982). Towards a cognitive redefinition of the social group. In H. Tajfel (Ed.), Social identity and intergroup relations (pp.15-40). Cambridge: Cambridge University Press.

Turner, J. C., Midgley, C., Meyer, D. K., Gheen, M., Anderman, E. M., Kang. Y., \& Patrick, H. (2002). The classroom environment and students' reports of avoidance strategies in mathematics: A multimethod study. Journal of Educational Psychology, 94, 88-106.

UNECE (United Nations Economic Commission for Europe). (2011). Learning for the future: Competences in Education for Sustainable Development. Retrieved August 6, 2013, from http://www.Ine.be/themas/natuur-en-milieueducatie/algemeen/nmeinternationaal/ECE_CEP_AC13_2011_6-20COMPETENCES-20EN.pdf

Van Poeck, K., \& Vandenabeele, J. (2013). Sustainable citizenship as practice. Lifelong Learning in Europe, 2. Retrieved from http://www.lline.fi/en/article/research/ 220135/sustainable-citizenship-as-practice

Vloet, K., \& Jacobs, G. (2012). Dialogic learning in teachers' professional identities. In B. Ligorio \& M. Cesar (Eds.), Interplays between dialogical learning and dialogical self (pp. 419-457). Charlotte, NC: Information Age Publishing, Inc.

Voci, A. (2006). The link between identification and in-group favouritism: Effects of threat to social identity and trust-related emotions. British Journal of Social Psycho$\log y, 45(2), 265-284$. doi: 10.1348/014466605X52245

Wenger, E. (1998). Communities of practice: Learning, meaning, and identity. Cambridge: Cambridge University Press.

Wilbert, L. T. (2008). High school mathematics teachers' perception of students with math anxiety. Retrieved August 6, 2013, from http://digitalscholarship.tnstate.edu/ dissertations/AAI3341932/

Woolfolk, A. E. (2007). Educational psychology (10 $10^{\text {th }}$ ed.). Boston, MA: Allyn \& Bacon. Zan, R., \& Di Martino, P. (2007). Attitude toward mathematics: Overcoming the positive/negative dichotomy. The Montana Mathematics Enthusiast, 3, 157-168.

Zan, R. S., Brown, L., Evans, J., \& Hannula, M. (2006). Affect in mathematics education: An introduction. Educational Studies in Mathematics, 63(2), 113-121.

Correspondence concerning this paper should be addressed to Dr Anita Pipere, the Institute of Sustainable Education, 1 Parādes Street 432, Daugavpils, LV-5401, Latvia. Email: anita.pipere@du.lv 
Appendix

Mathematics and its meaning (general context)

1. What is mathematics? What concepts, images and associations come to your mind?

2. What do you feel when you are doing or teaching mathematics, or carrying research on the issues related to mathematics?

Doing mathematics: social, institutional and self-evaluation

1. How did/do your contemporaries perceive you as a university student of mathematics, a teacher of mathematics, an author of teaching aids, a researcher in the field of mathematics?

2. How did/do you perceive it?

3. How does society in Latvia perceive doing mathematics in present economic conditions (before the crisis and during the crisis)?

Relationships with mathematics from different social positions

1. Please, characterise your personal relationships with mathematics beginning from the kindergarden/school until the present moment.

2. What changes happened in your personal relationships with mathematics due to changes in your social positions (a pupil, a university student, a teacher, a doctoral student, a university teacher etc.)?

3. Which positions brought the largest changes in your relationships with mathematics?

4. What factors had the strongest impact on these changes?

Mathematical philia and phobia: Concept, causes, fostering/impeding factors

How could you comment on mathematical philia/phobia?

1. Suggest the causes of your own mathematical philia (or phobia).

2. Characterise mathematical philia/phobia in your social surroundings and institutional context (your classmates, group mates, colleagues, subordinates, students, scientific advisors, colleagues in doctoral studies etc.).

3. What factors did you notice as eliciting their specific attitude towards mathematics?

4. What would you suggest sustaining the mathematical philia and avoiding the mathematical phobia for mathematic learners at different levels?

5. What are you future plans and intentions in relation to mathematics? 